\title{
Synthesis of Imidazole and Indole Hybrid Molecules and Antifungal Activity against Rice Blast
}

\author{
Tomio Sumiya, Mai Ishigaki, and Keimei Oh
}

\begin{abstract}
Azole and indole are parent substances of many natural and synthetic compounds with significant biological activity. However, the biological activity of the indole and azole conjugates are lack of investigation. In the present work, a series of hybrid molecules with imidazole and indole moiety were designed by using camalexin as a molecular scaffold. Compounds with different length of the carboxylic acid (4a-4f) were prepared. The antifungal activity of this synthetic series together with the ethyl esters analogues (3a-3f) against Magnaporthe oryzae were determined by using agar cup plate assay. Data obtained from the structure-activity relationship studies indicated that the ester analogues displayed antifungal activity against Magnaporthe oryzae while the carboxylic acid derivatives did not. This result indicated that the carboxylic acid ethyl ester moiety is important to antifungal activity. Among all the synthesized compounds, we found that, at a concentration of $100 \mu \mathrm{M}$, compound $3 \mathrm{c}$ displays the most potent inhibition activity with $38.8 \pm 2.5 \%$ on the inhibition of the diameter of the mycelial mat of Magnaporthe oryzae while the positive control of propiconazole $(10 \mu \mathrm{M})$ was found $39.3 \pm 2.9 \%$.
\end{abstract}

Index Terms-Antifungal activity, imidazole, indole, rice blast.

\section{INTRODUCTION}

There are tremendous needs to control pathogenic microbes for health care and in agricultural industry. The chemicals that either kill or display inhibitory activity on microbial growth are currently the major solutions for pathogenic microbe control [1].

Rice blast disease (RBD) which is caused by the pathogenic fungi of $M$. oryzae, is a leading constraint in world rice production [2]. The high incidence of plant mortality and the lack of effective control methods cause billions of dollars in losses worldwide each year. Hence, great efforts and various management strategies have been made to control the RBD [3] inimize the severity of RBD [4].

Some fungicides are targeting membranes functions due to the cell order and integrity of microbial membrane are significantly important. Chemicals that directly or indirectly target membranes functions or their components synthesis are quite effective to cause the lethality of the microbes thereby controlling the microbial disease.

Several chemical structures have been found effective on killing or inhibiting the microbial growth which including indole [5] and azole derivatives [6]. Some indole derivatives

Manuscript received February 18, 2017; revised May 7, 2017.

The authors were with the Department of Biotechnology, Akita Prefectural University, 241-438, Shimoshinjo Nakano Akita-Shi, Akita 010-0195 Japan (e-mail: K.O. e-mail: jmwang@akita-pu.ac.jp). has been found with broad spectrum of antimicrobial activity [5]. Many indole scaffold antimicrobial agents have been well investigated [7]-[9]. On the other hand, azole derivatives are also well known antimicrobial agents [6]. The action mechanism of azoles is believed that they targeting the P450 enzymes involved in the biosynthesis of sterol [10]. It is known that azole derivatives have widespread ability to function as cytochrome P450 inhibitors [11], apparently due to the intrinsic affinity of the nitrogen electron pair in heterocyclic molecules for the prosthetic heme iron [12]. The azoles thus bind not only to lipophilic regions of the protein, they also simultaneously bind to the prosthetic heme iron [13] thereby prevent the enzyme-substrate interactions. There are many azole derivatives which serve as potent fungicidal agent and some of which are commercially available [14]-[16].

In spite of the antimicrobial activity of indole and azole derivatives have been investigated extensively, the biological activity of the conjugates of these core structure against pathogenic fungi is lack of investigation. In the present work, we designed an indole-imidazole conjugate using Camalexin (3-thiazol-2'-yl-indole) (Fig. 1), the end product of tryptophan pathways and the major phytoalexin of Arabidopsis. We report herein the synthesis and biological evaluation of the fungicide activity of indole-imidazole conjugate compounds against $M$. oryzae.

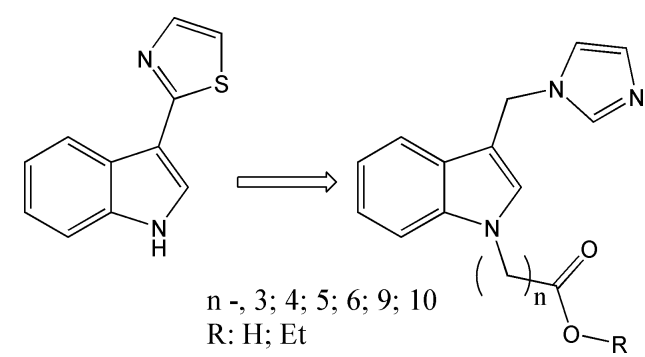

Fig. 1. Molecular design of indole-imidazole conjugates based on Camalexin scaffold.

\section{MATERIALS AND METHODS}

\section{A. General}

Stock solutions of all the test compound were dissolved in DMSO at a concentration of $100 \mathrm{mM}$ and stocked at $-30^{\circ} \mathrm{C}$. Other reagents were of the highest grade and purchased from Wako Pure Chemical Industries, Ltd. (Tokyo, Japan). ${ }^{1} \mathrm{H}-\mathrm{NMR}$ spectra were recorded with a JEOL ECP-400 spectrometer (Tokyo, Japan), chemical shifts being expressed in ppm down TMS as an internal standard. High resolution electrospray ionization Fourier transform ion cyclotron resonance mass spectra (ESI were recorded on an Exactive MS System (Thermo Fisher Scientific, Waltham, MA, USA). 


\section{B. Chemical Synthesis}

Preparation of 3-(1H-imidazol)-1-Indole (2) was carried out by a method as previously described [17]. A solution of $1 \mathrm{H}$ indole-3-methanol (1a; $294 \mathrm{mg}, 2 \mathrm{mmol})$ and CDI (420 $\mathrm{mg}, 2.6 \mathrm{mmol}, 1.3$ equiv) in anhyd $\mathrm{MeCN}$ (5ml) was stirring at room temperature for $5 \mathrm{~h}$. The reaction mixture was worked up and diluted with cold water $(20 \mathrm{ml})$ and the resulting precipitate was collected, washed with water and dried under vacuum at $40-50^{\circ} \mathrm{C}$. Recrystallization were carried out by using anhydride $\mathrm{MeCN}$ to give pure 3-(1H-imidazo- 1-ylmethyl)-1H-Indole (2) (Yield 92\%), ${ }^{1} \mathrm{H}$ $\mathrm{NMR}\left(\mathrm{CDCl}_{3}\right), \delta: 5.31(2 \mathrm{H}, \mathrm{s}), 6.96(1 \mathrm{H}, \mathrm{s}), 7.05(1 \mathrm{H}, \mathrm{s}), 7.13$ $(1 \mathrm{H}, \mathrm{t}, J=7.1), 7.18(1 \mathrm{H}, \mathrm{d}, J=2.3), 7.23(1 \mathrm{H}, \mathrm{d}, J=8.2), 7.43$ $(2 \mathrm{H}, \mathrm{J} 2=12.0), 7.59(1 \mathrm{H}, \mathrm{s}), 8.23(1 \mathrm{H}, \mathrm{s})$.

Preparation of 4-(3-Imidazol-1-ylmethyl-indol-1-yl)butyric acid ethyl ester (3a) was carried out by a method as we previously described [18]. Stirring $40 \mathrm{mg}$ of $\mathrm{NaH}$ (approximately $60 \%$ pure, $1 \mathrm{mmol}$ ) in a suspension of anhydride DMF $(2 \mathrm{ml})$ in a $50 \mathrm{ml}$ flask on ice. A solution of 3-(1H-imidazol-1-Indole in anhydride DMF (containing 197 $\mathrm{mg}, 1 \mathrm{mmol}$ ) was added dropwise and stirred for $30 \mathrm{~min}$ at room temperature. Then, 4-bromobutric acid ethyl ester (187 $\mathrm{mg}, 1 \mathrm{~mol}$ ) was added dropwise and stirred for 5 hour at room temperature. The reaction was quenched by added $\mathrm{H}_{2} \mathrm{O}$. The DMF was removed by extraction of target compound with three times of chloroform $(20 \mathrm{ml})$. The organic layer was combined and dried with anhydride $\mathrm{Na}_{2} \mathrm{SO}_{4}$. The solvent was removed by concentration under reduced pressure gave $67 \mathrm{mg}$ of 3a. Yield: $40.3 \% .{ }^{1} \mathrm{H} \mathrm{NMR}\left(\mathrm{CDCl}_{3}\right) . \delta: 1.21-1.25(\mathrm{~m}, 3 \mathrm{H})$, 2.13-2.19 (m, 2H), 2.29 ( $t, J=6.18 \mathrm{~Hz}, 2 \mathrm{H}), 4.08-4.13(\mathrm{~m}, 2 \mathrm{H})$, 4.18-4.21 (m, 2H), 5.31-5.35 (m, 2H), $7.00(\mathrm{~s}, 1 \mathrm{H}), 7.09-7.14$ $(\mathrm{m}, 3 \mathrm{H}), 7.24-7.26(\mathrm{~m}, 1 \mathrm{H}), 7.40\left(\mathrm{q}, J_{1}=8.01, J_{2}=15.0 \mathrm{~Hz}, 2 \mathrm{H}\right)$, $7.78(\mathrm{~d}, J=10.1 \mathrm{~Hz}, 1 \mathrm{H})$. The HRMS-ESI calculated for $\mathrm{C}_{12} \mathrm{H}_{22} \mathrm{~N}_{3}[\mathrm{M}+\mathrm{H}]^{+}$was 312.1712 , and 312.1707 was the experimental value.

Other compounds were prepared in a similar way gave yield from $48 \%$ to $62 \%$.

5-(3-Imidazol-1-ylmethyl-indol-1-yl)-pentanoic acid ethyl ester (3b) Yield: $74.0 \%,{ }^{1} \mathrm{H} \mathrm{NMR}\left(\mathrm{CDCl}_{3}\right) . \delta: 1.21-1.25(\mathrm{~m}$, $3 \mathrm{H}), 1.57-1.68(\mathrm{~m}, 2 \mathrm{H}), 1.84-1.91(\mathrm{~m}, 2 \mathrm{H}), 2.30-2.33(\mathrm{t}$, $J=7.33 \mathrm{~Hz}, 2 \mathrm{H}), 4.08-4.14(\mathrm{~m}, 4 \mathrm{H}), 5.30$ (s, 2H),

$6.97(\mathrm{t}, J=1.14,1 \mathrm{H}), 7.06-7.13(\mathrm{~m}, 3 \mathrm{H}), 7.23-7.27(\mathrm{~m}, 1 \mathrm{H})$, $7.34(\mathrm{dd}, J=0.92,7.33 \mathrm{~Hz}, 1 \mathrm{H}), 7.42$ (dd, $J=0.69,7.33 \mathrm{~Hz}$, 1H), $7.70(\mathrm{~d}, J=6.87 \mathrm{~Hz}, 1 \mathrm{H})$. The HRMS-ESI calculated for $\mathrm{C}_{12} \mathrm{H}_{24} \mathrm{~N}_{3}[\mathrm{M}+\mathrm{H}]^{+}$was 326.1869 , and 326.1863 was the experimental value.

6-(3-Imidazol-1-ylmethyl-indol-1-yl)-hexanoic acid ethyl ester (3c). Yield: $66.8 \% .{ }^{1} \mathrm{H} \mathrm{NMR}\left(\mathrm{CDCl}_{3}\right) . \delta: 1.20-1.24(\mathrm{~m}$, $3 \mathrm{H}), 1.30-1.37(\mathrm{~m}, 2 \mathrm{H}), 1.61-1.69(\mathrm{~m}, 2 \mathrm{H}), 1.80-1.88(\mathrm{~m}, 2 \mathrm{H})$, $2.27(\mathrm{t}, J=7.33 \mathrm{~Hz}, 2 \mathrm{H}), 4.07-4.13(\mathrm{~m}, 4 \mathrm{H}), 5.27$ (s, 2H), 6.95 $(\mathrm{d}, J=1.37,1 \mathrm{H}), 7.03(\mathrm{~d}, J=0.69,1 \mathrm{H}), 7.06(\mathrm{~s}, 1 \mathrm{H}), 7.10(\mathrm{t}$, $J=7.10 \mathrm{~Hz}, 1 \mathrm{H}), 7.21-7.27$ (m, 1H), 7.33 (d, $J=8.24 \mathrm{~Hz}, 1 \mathrm{H})$, $7.42(\mathrm{~d}, J=7.79 \mathrm{~Hz}, 1 \mathrm{H}), 7.59(\mathrm{~s}, 1 \mathrm{H})$. The HRMS-ESI calculated for $\mathrm{C}_{12} \mathrm{H}_{26} \mathrm{~N}_{3}[\mathrm{M}+\mathrm{H}]^{+}$was 340.2025 , and 340.2020 was the experimental value.

7-(3-Imidazol-1-ylmethyl-indol-1-yl)-heptanoic acid ethyl ester (3d). Yield: $85.6 \%$. ${ }^{1} \mathrm{H} \mathrm{NMR}\left(\mathrm{CDCl}_{3}\right) . \delta: 1.22-1.26(\mathrm{~m}$, $3 \mathrm{H}), 1.33-1.34(\mathrm{~m}, 4 \mathrm{H}), 1.57-1.62(\mathrm{~m}, 2 \mathrm{H}), 1.76-1.87(\mathrm{~m}, 2 \mathrm{H})$, 2.25-2.29 (m, 2H), 4.08-4.14 (m, 4H), 5.31 (d, 2H), 6.97-6.98 $(\mathrm{m}, 1 \mathrm{H}), 7.06-7.13(\mathrm{~m}, 3 \mathrm{H}), 7.22-7.27(\mathrm{~m}, 1 \mathrm{H}), 7.34(\mathrm{~d}$, $J=8.24 \mathrm{~Hz}, 1 \mathrm{H}), 7.42(\mathrm{~d}, J=8.01 \mathrm{~Hz}, 1 \mathrm{H}), 7.71(\mathrm{~d}, J=12.59 \mathrm{~Hz}$, $1 \mathrm{H})$. The HRMS-ESI calculated for $\mathrm{C}_{12} \mathrm{H}_{28} \mathrm{~N}_{3}[\mathrm{M}+\mathrm{H}]^{+}$was 354.2182 , and 354.2176 was the experimental value.

10-(3-Imidazol-1-ylmethyl-indol-1-yl)-decanoic acid ethyl ester (3e). Yield: 30.1\%. ${ }^{1} \mathrm{H} \mathrm{NMR}\left(\mathrm{CDCl}_{3}\right) . \delta: 1.25-1.30(\mathrm{~m}$, $13 \mathrm{H}), 1.60(\mathrm{t}, J=6.18 \mathrm{~Hz}, 2 \mathrm{H}), 1.82(\mathrm{t}, J=5.61 \mathrm{~Hz}, 2 \mathrm{H})$, 2.25-2.29 (m, 2H), 4.07-4.15 (m, 4H), $5.30(\mathrm{~s}, 2 \mathrm{H}), 6.98(\mathrm{~s}$, $1 \mathrm{H}), 7.08-7.13(\mathrm{~m}, 3 \mathrm{H}), 7.22-7.26(\mathrm{~m}, 1 \mathrm{H}), 7.35$ (d, J=8.24 $\mathrm{Hz}, 1 \mathrm{H}), 7.39-7.43(\mathrm{~m}, 1 \mathrm{H}), 7.74(\mathrm{~s}, 1 \mathrm{H})$. The HRMS-ESI calculated for $\mathrm{C}_{12} \mathrm{H}_{34} \mathrm{~N}_{3}[\mathrm{M}+\mathrm{H}]^{+}$was 396.2651 , and 396.2646 was the experimental value.

11-(3-Imidazol-1-ylmethyl-indol-1-yl)-undecanoic acid ethyl ester (3f). Yield: $63.8 \% \quad .{ }^{1} \mathrm{H} \quad \mathrm{NMR}\left(\mathrm{CDCl}_{3}\right) . \quad \delta$ : $1.23-1.30(\mathrm{~m}, 15 \mathrm{H}), 1.60(\mathrm{t}, J=6.18 \mathrm{~Hz}, 2 \mathrm{H}), 1.82(\mathrm{t}, J=6.07$ $\mathrm{Hz}, 2 \mathrm{H}), 2.26-2.30$ (m, 2H), 4.08-4.15 (m, 4H), 5.33 (s, 2H), $6.99(\mathrm{~s}, 1 \mathrm{H}), 7.09-7.13(\mathrm{~m}, 3 \mathrm{H}), 7.23-7.27(\mathrm{~m}, 1 \mathrm{H}), 7.36(\mathrm{~d}$, $J=8.24 \mathrm{~Hz}, 1 \mathrm{H}), 7.42$ (d, J=7.90 Hz, 1H), 7.80 (s, 1H). The HRMS-ESI calculated for $\mathrm{C}_{12} \mathrm{H}_{36} \mathrm{~N}_{3}[\mathrm{M}+\mathrm{H}]^{+}$was 410.2808 , and 410.2802 was the experimental value.

Preparation of 4-(3-imidazol-1-ylmethyl-indol-1-yl)butyric acid (4a) was carried out by hydrolysis the corresponding ethyl esters in a basic condition using $\mathrm{KOH}$ in a solution of $\mathrm{MeOH}$ and $\mathrm{H}_{2} \mathrm{O}\left(1 \mathrm{M} \mathrm{KOH}, 20 \mathrm{~mL}, \mathrm{MeOH}: \mathrm{H}_{2} \mathrm{O}\right.$ $=1: 1$ ). The reaction mixture was allowed stirring for $3-4 \mathrm{~h}$. The reaction was worked up by acidified $(\mathrm{pH} 2$ using $1 \mathrm{~N} \mathrm{HCl}$ ) and the target compound was extracted by ethyl acetate. The organic layers were combined and dried with $\mathrm{Na}_{2} \mathrm{SO}_{4}$. The solvent was removed in a reduced pressure. The resulting oil was purified by silica gel column chromatography and PTLC gave pure 4a. Yield: $13.0 \%$, oil, ${ }^{1} \mathrm{H}$ NMR $(400 \mathrm{MHz}$, MeOH-D 4 ) $\delta: ~ 2.10-2.22(m, 2 H), 3.37(\mathrm{~s}, 1 \mathrm{H}), 4.22-4.26(\mathrm{t}$, $J=6.9 \mathrm{~Hz}, 2 \mathrm{H}), 5.39$ (s, 2H), 6.95 (s, 1H), $7.03-7.21(\mathrm{~m}, 4 \mathrm{H})$, 7.40-7.49 (m, 4H), 7.78 (s, 1H). The HRMS-ESI calculated for $\mathrm{C}_{16} \mathrm{H}_{17} \mathrm{~N}_{3} \mathrm{O}_{2}[\mathrm{M}-\mathrm{H}]^{-}$was 282.1243 , and 282.1245 was the experimental value. Other compounds were prepared in a similar way gave $\mathbf{4 b - 4 e}$.

5-(3-Imidazol-1-ylmethyl-indol-1-yl)-pentanoic acid (4b). Yield: $14.5 \%$, oil, ${ }^{1} \mathrm{H}$ NMR (400 MHz, MeOH-D $\left.{ }_{4}\right) \delta$ : 1.57-1.65 (m, 2H), 1.84-1.96 (m, 2H), 2.24-2.27 (t, $J=7.3 \mathrm{~Hz}$, $2 \mathrm{H}), 3.32-3.34(\mathrm{~m}, 2 \mathrm{H}), 4.18-4.22(\mathrm{t}, J=7.1 \mathrm{~Hz}, 2 \mathrm{H}), 5.38(\mathrm{~s}$, $2 \mathrm{H}), 6.97(\mathrm{~s}, 1 \mathrm{H}), 7.03-7.07(\mathrm{~m}, 1 \mathrm{H}), 7.15-7.21(\mathrm{~m}, 1 \mathrm{H})$, 7.39-7.45 (m, 4H), $7.81(\mathrm{~s}, 1 \mathrm{H})$. The HRMS-ESI calculated for $\mathrm{C}_{17} \mathrm{H}_{19} \mathrm{~N}_{3} \mathrm{O}_{2}[\mathrm{M}-\mathrm{H}]^{-}$was 296.1399 , and 296.1398 was the experimental value.

6-(3-Imidazol-1-ylmethyl-indol-1-yl)-hexanoic acid (4c). Yield: $8.9 \%$, oil, ${ }^{1} \mathrm{H}$ NMR (400 MHz, MeOH-D $\left.{ }_{4}\right)$ $\delta: 1.58-1.64(\mathrm{~m}, 2 \mathrm{H}), 1.83-1.90(\mathrm{~m}, 2 \mathrm{H}), 2.20-2.23(\mathrm{~m}, 2 \mathrm{H})$, 4.21-4.24 (m, 2H), 5.39 (s, 2H), 6.98-7.07 (m, 3H), 7.18-7.23 $(\mathrm{m}, 3 \mathrm{H}), 7.41-7.46(\mathrm{~m}, 4 \mathrm{H}), 7.74(\mathrm{~s}, 1 \mathrm{H})$. The HRMS-ESI calculated for $\mathrm{C}_{18} \mathrm{H}_{21} \mathrm{~N}_{3} \mathrm{O}_{2}[\mathrm{M}-\mathrm{H}]^{-}$was 310.1556 , and 310.1556 was the experimental value.

7-(3-Imidazol-1-ylmethyl-indol-1-yl)-heptanoic acid (4d). Yield: $11.0 \%$, oil, ${ }^{1} \mathrm{H}$ NMR (400 MHz, MeOH-D 4$)$ $\delta: 1.30-1.39(\mathrm{~m}, 5 \mathrm{H}), 1.53-1.61(\mathrm{~m}, 2 \mathrm{H}), 1.82-1.89(\mathrm{~m}, 2 \mathrm{H})$, 2.20-2.24 (t, $J=7.3 \mathrm{~Hz}, 2 \mathrm{H}), 4.17-4.21(\mathrm{t}, J=6.9 \mathrm{~Hz}, 2 \mathrm{H}), 5.40$ (s, 2H), $7.00(\mathrm{~s}, 1 \mathrm{H}), 7.04-7.07(\mathrm{~m}, 1 \mathrm{H}), 7.18-7.22(\mathrm{~m}, 2 \mathrm{H})$, 7.38-7.47 (m, 3H), $7.85(\mathrm{~s}, 1 \mathrm{H})$. The HRMS-ESI calculated for $\mathrm{C}_{19} \mathrm{H}_{23} \mathrm{~N}_{3} \mathrm{O}_{2}[\mathrm{M}-\mathrm{H}]^{-}$was 324.1712 , and 324.1713 was the experimental value. 
<smiles>OCc1c[nH]c2ccccc12</smiles>

$\stackrel{\text { (ii) }}{\longrightarrow}$<smiles>CCOC(=O)Cn1cc(Cn2ccnc2)c2ccccc21</smiles>

3a-3f

Conditions: (i) CDI, MeCN, r.t., 5 h.(ii) 1, $\mathrm{NaH}$, DMF, 2, $\mathrm{Br}\left(\mathrm{CH}_{2}\right)$ nCOOEt.(iii) $\mathrm{KOH}$<smiles>Cn1cc(Cn2ccnc2)c2ccccc21</smiles>

4a-4f Scheme 1 . General method of synthesis the target compounds

10-(3-Imidazol-1-ylmethyl-indol-1-yl)-decanoic acid (4e). Yield: $4.2 \%$, oil, ${ }^{1} \mathrm{H}$ NMR (400 MHz, MeOH-D $)$ $\delta: 1.30-1.36(\mathrm{~m}, 5 \mathrm{H}), 1.57-1.60(\mathrm{~m}, 2 \mathrm{H}), 1.83-1.93(\mathrm{~m}, 5 \mathrm{H})$, $3.32-3.34(\mathrm{~m}, 2 \mathrm{H}), 4.17-4.21(\mathrm{t}, J=7.1 \mathrm{~Hz}, 2 \mathrm{H}), 5.38(\mathrm{~s}, 2 \mathrm{H})$, $6.95(\mathrm{~s}, 1 \mathrm{H}), 7.03-7.13(\mathrm{~m}, 1 \mathrm{H}), 7.18-7.22(\mathrm{~m}, 2 \mathrm{H}), 7.37-7.47$ $(\mathrm{m}, 4 \mathrm{H}), 7.74(\mathrm{~s}, 1 \mathrm{H})$. The HRMS-ESI calculated for $\mathrm{C}_{22} \mathrm{H}_{29} \mathrm{~N}_{3} \mathrm{O}_{2}[\mathrm{M}-\mathrm{H}]^{-}$was 366.2182 , and 366.2176 was the experimental value.

11-(3-Imidazol-1-ylmethyl-indol-1-yl)-undecanoic acid (4f). Yield: 5.7\%, oil, ${ }^{1} \mathrm{H}$ NMR (400 MHz, MeOH-D $\left.{ }_{4}\right)$ $\delta: 1.27-1.30(\mathrm{~m}, 4 \mathrm{H}), 1.56-1.61(\mathrm{~m}, 3 \mathrm{H}), 1.83-1.86(\mathrm{~m}, 3 \mathrm{H})$, 2.21-2.25 (m, 4H), 3.32-3.34 (m, 2H), 4.17-4.21 (m, 2H), $5.39(\mathrm{~s}, 2 \mathrm{H}), 6.97(\mathrm{~s}, 1 \mathrm{H}), 7.04-7.08(\mathrm{~m}, 2 \mathrm{H}), 7.16-7.22(\mathrm{~m}$, $3 \mathrm{H}), 7.37(\mathrm{~s}, 1 \mathrm{H}), 7.41-7.48(\mathrm{~m}, 3 \mathrm{H}), 7.79(\mathrm{~s}, 1 \mathrm{H})$. The HRMS-ESI calculated for $\mathrm{C}_{23} \mathrm{H}_{31} \mathrm{~N}_{3} \mathrm{O}_{2}[\mathrm{M}-\mathrm{H}]^{-}$was 380.2338 , and 380.2335 was the experimental value.

\section{Magnaporthe oryzae Strain and Bioassay}

Rice blast isolate designated as APU00-093A (race 007.0), was obtained by mono-spore isolation from diseased rice panicle on a paddy field from the Akita Prefecture, Japan, in 2000 was kindly provided from Dr. S. Fuji of Akita Prefectural University. This isolate was kept on Potato Dextrose Agar (PDA) at $15^{\circ} \mathrm{C}$. Determine the fungicidal activity of the test compounds was based on a method as we described previously [19].

\section{RESULTS AND DISCUSSION}

\section{A. Chemistry}

Method for synthesis the target compounds is shown in Scheme 1 in a condition as previously reported [8]. 3-Indolemethanol (1) was used as starting materials. Compound 2 was prepared by reacting compound 1 with 1.3 equivalent of 1, 1' carbonylbis-1H-imidazole in anhydride acetonitrile at room temperature for 5 hours. The reaction was monitored by using TLC until the starting material 1 is disappeared. Compound $\mathbf{2}$ was purified by recrystallization of crude compound $\mathbf{2}$. The target compounds 3a-3f were prepared by using $\mathrm{NaH}$ in DMF following adding $\omega$-bromocarboxlic acid ethyl ester based on a method as previously reported [18].

\section{B. Biology}

To determine the antifungal activity of the synthesized compounds against $M$. oryzae, Mycelial growth inhibition tests were carried out [19]. The concentration of all the test compounds were adjusted to a final concentration of $100 \mu \mathrm{M}$ in PSA medium, while propiconazole $(10 \mu \mathrm{M})$ was used as a positive control.

TABLE I: FunGICIDAL ACTIVITY OF ETHYL ESTER DERIVATIVES

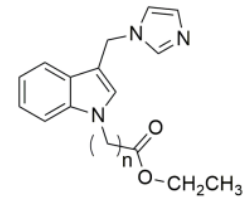

\begin{tabular}{c|c|c}
\hline \hline Com. No. & $n$ & Inhibition Activity (\%) \\
\hline \hline $3 \mathrm{a}$ & 3 & $6.16 \pm 1.1$ \\
\hline $3 \mathrm{~b}$ & 4 & $21.2 \pm 2.4$ \\
\hline $3 \mathrm{c}$ & 5 & $38.8 \pm 2.5$ \\
\hline $3 \mathrm{~d}$ & 6 & $36.5 \pm 4.6$ \\
\hline 3e & 9 & $18.3 \pm 2.9$ \\
\hline 3f & 10 & $5.53 \pm 1.5$ \\
\hline Propiconazole & $39.3 \pm 2.9$ \\
\hline
\end{tabular}

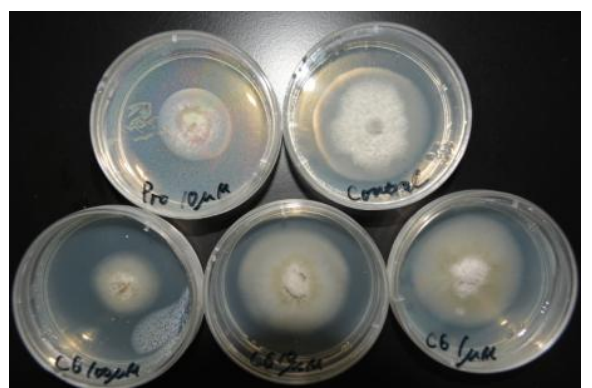

Fig. 2. Effect of compound 3c on growth of M. oryzae, upper left: 10 M; propiconazole, upper right: control; lower left. $0.1 \mathrm{mM} \mathrm{3c}$, lower middle: $10 \mathrm{M} \mathrm{3c}$, lower right, 1 M 3c, All the experiments were taken three times to establish the repeatability.

Table I shows the chemical structure and the antifungal activity of the ethyl ester derivatives (3a-3f).We found that the inhibition activity of butric acid ethyl ester (3a) was approximately $6.16 \pm 1.1$. Increasing the carbon number of the carboxylic acid side chain enhanced the inhibitory activity with $21.2 \pm 2.4,38.8 \pm 2.5$ and $36.5 \pm 4.6 \%$ for those analogues of pentanic acid ethyl ester (3b), hexanic acid ethyl ester (3c) and heptanic acid ethyl ester (3d), respectively. In contrast, the inhibitory activity of the positive control of propiconazole $(10 \mathrm{mM})$ was found approximately $39.3 \pm 2.9 \%$. this result indicated that compound 3c displayed inhibitory activity against M. oryzae is approximately one tenth of the propiconazole.

Fig. 2 displayed the growth of Magnaporthe oryzae in the absence and presence of compound 3c. Data obtained clearly indicated that compound $\mathbf{3 c}$ inhibits the Magnaporthe oryzae growth in our assay system. This result suggested that the modifications that may allow us to find a new series of 
antifungal agent against $\mathrm{M}$. oryzae.

Table II shows the chemical structure and the antifungal activity of the carboxylic acid derivatives $(\mathbf{4 a - 4 f})$. We found that the inhibition activity decreased significantly. This result compound $\mathbf{3 c}$ is a good candidate for further chemical indicated that carboxylic acid ester moiety is important for antifungal activity against $M$. oryzae in this synthetic series.

\begin{tabular}{|c|c|c|}
\hline Com. No. & $n$ & Inhibition Activity (\%) \\
\hline $4 a$ & 3 & $4.15 \pm 2.5$ \\
\hline $4 \mathrm{~b}$ & 4 & $2.59 \pm 3.0$ \\
\hline $4 \mathrm{c}$ & 5 & $2.22 \pm 3.9$ \\
\hline $4 d$ & 6 & $5.49 \pm 2.0$ \\
\hline $4 \mathrm{e}$ & 9 & $3.22 \pm 4.0$ \\
\hline $4 \mathrm{f}$ & 10 & $4.80 \pm 4.2$ \\
\hline \multicolumn{2}{|c|}{ Propiconazole } & $39.3 \pm 2.9$ \\
\hline
\end{tabular}

\section{CONCLUSIONS}

To determine the antifungal activity of indole and imidazole conjugate against $M$. oryzae, we designed a series of new compounds based on the Camalexin scaffold. The ethyl ester analogues displayed antifungal activity against $M$. oryzae. We found that compound $\mathbf{3 c}$ displayed the most potent inhibitory activity against $M$. oryzae Data obtained in the present work indicated that the carboxlic acid analogues did not exhibit inhibitory activity against $M$. oryzae This result suggested that the carboxlic acid ester moiety is important for antifungal activity. We expect further chemical modification of this synthetic series may allow us to discover new compounds for $M$. oryzae control.

\section{ACKNOWLEDGMENT}

We thank professor S. Fuji of Akita prefectural University for his gift of Magnaporthe oryzae strain. This work is partially supported by a grand of industrial-academic cooperation project of Akita Prefectural University to Keimei $\mathrm{Oh}$

\section{REFERENCES}

[1] L. Sundar and F. M. Chan, "Antimicrobial activity and biosynthesis of indole antibiotics produced by Xenorhabdus nematophilus," J. Gen. Microbiol. vol.139, pp.3139-3148, Dec. 1993.

[2] N. J. Talbot "On the trail of a cereal killer: exploring the biology of Magnaporthe grisea," Annual Reviews of Microbiology, vol. 57, pp. 177-202, Jan. 2003.

[3] S. C. Knight, V. M. Anthony, A. M. Brady et al., "Rationale and perspectives on the development of fungicides," Annual Review of Phytopathology, vol. 35, pp. 349-372, Jan. 1997.

[4] B. C. Baldwin and W. G. Rathmell, "Evolution of concepts for chemical control of plant disease," Annual Review of Phytopathology vol. 26, pp. 265-283, Jan. 1988.

[5] A. Özdemir, M. D. Altintop, Z. A. Kaplancıklı A. G. Turan-Zitouni, H. Karaca, and Y. Tunalı, "Synthesis and biological evaluation of pyrazoline derivatives bearing an indole moiety as new antimicrobial agents," Arch Pharm (Weinheim), vol. 346, pp. 463-469, Jun. 2013.
[6] M. S. Saag and W. E. Dismukes, "Azole antifungal agents: emphasis on new triazoles," Antimicrob Agents Chemother, vol. 32, pp.1-8, Jan. 1988.

[7] A. Paudel, H. Hamamoto, Y. Kobayashi, S. Yokoshima, T. Fukuyama, and K. Sekimizu. "Identification of novel deoxyribofuranosyl indole antimicrobial agents," J. Antibiot. (Tokyo), vol. 65, pp. 53-57, Feb. 2012.

[8] R. Rohini, P. M.Reddy, K. Shanker, K. Kanthaiah, V. Ravinder, and A. $\mathrm{Hu}$, "Synthesis of mono, bis-2-(2-arylideneaminophenyl) indole azomethines as potential antimicrobial agents," Arch. Pharm. Res. vol. 34, pp. 1077-1084, July 2011.

[9] G. Gurkok, N. Altanlar, and S. Suzen. "Investigation of antimicrobial activities of indole-3-aldehyde hydrazide/hydrazone derivatives," Chemotherapy, vol. 55, pp. 15-19, Jan. 2009.

[10] X. M. Peng, G. X. Cai, and C. H. Zhou. "Recent developments in azole compounds as antibacterial and antifungal agents," Curr Top Med Chem. vol. 13, pp. 1963-2010, Aug. 2013.

[11] J. A. Zarn, B. J. Brüschweiler, and J. R. Schlatter, “Azole fungicides affect mammalian steroidogenesis by inhibiting sterol 14 alpha-demethylase and aromatase," Environ Health Perspect., vol. 111, pp. 255-261, Mar. 2003.

[12] M. Murray, "Mechanisms and significance of inhibitory drug interactions involving cytochrome P450 enzymes," Int J Mol Med., vol. 3, pp. 227-238, Mar. 1999.

[13] T. D. Rogerson, C. F. Wilkinson, and K. Hetarski, "Steric factors in the inhibitory interaction of imidazoles with microsomal enzymes," Biochem Pharmacol., vol. 26, pp.1039-1042, Jun. 1977.

[14] A. A. Bekhit, A. Hymete, A. El-Din, A. Bekhit, A. Damtew, and H. Y. Aboul-Enein, "Pyrazoles as promising scaffold for the synthesis of anti-inflammatory and/or antimicrobial agent: A review," Mini Rev Med Chem., vol. 10, pp.1014-1033, Oct. 2010.

[15] V. Padmavathi, C. Prema Kumari, B. C. Venkatesh, and A. Padmaja, "Synthesis and antimicrobial activity of amido linked pyrrolyl and pyrazolyl-oxazoles, thiazoles and imidazoles," Eur. J. Med. Chem. vol. 46, pp. 5317-5326, Nov. 2011.

[16] S. Basoglu, M. Yolal, S. Demirci, N. Demirbas, H. Bektas, and S. A Karaoglu, "Design, synthesis and antimicrobial activities of some azole derivatives," Acta Pol. Pharm., vol. 70, pp. 229-236, Mar-Apr. 2013.

[17] K. Oh, M. Ishigaki, T. Hoshi, and Y. Yoshizawa, "Synthesis of novel imidazole derivatives based on camalexin scaffold and anti-fungal activity against rice blast," Bri. J. App. Sci. Tech., vol. 9, pp. 527-533, June 2015

[18] K. Oh, M. Ishigaki, T. Hoshi, Y. Yoshizawa, and Y. Shimura, "Synthesis of new indole derivatives structurally related to camalexin and biological evaluation of antibacterial activity," Inter. J. Adv. Sci. Eng. Tech., vol. 4s, pp.195-198. May 2016.

[19] T. Hoshi, K. Yamada, Y. Yoshizawa, and K. Oh, "Structure-activity relationship study for fungicidal activity of 1-(4-phenoxymethyl2-phenyl-[1,3]dioxolan-2-ylmethyl)-1H-1,2,4-triazole derivatives against rice blast," J. Plant Prot. Res., vol. 55, pp. 383-388, Oct. 2015.

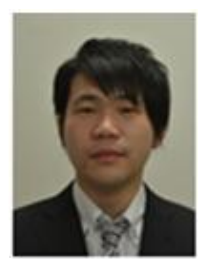

Sumiya Tomio was born in Mie Prefecture, Japan. He received his bachelors' degree from the Department of Biotechnology, Akita Prefectural University in 2017. Currently, he is a graduate student working in the field of chemical biology of plant hormone. One of his research theme is to visualize the plant hormone actions through using fluorescent techniques. Using fluorescent labeled probe of brassinosteriod biosynthesis inhibitors as well as chemicals with ethylene activity, he is now working on the determination of the biological actions of these new chemicals.

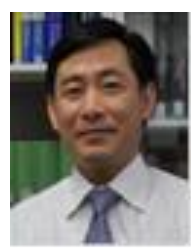

Keimei Oh was born in Shanghai, China and received his Ph.D. degree from the University of Tokyo in 1997. $\mathrm{He}$ is currently serving as an associate professor at the Department of Biotechnology, Akita Prefectura University, Japan. His research interests are the design and synthesis specific inhibitors of plant hormone biosynthesis and study the mode of action of bio-active chemicals. 